\title{
The Attitude of Teachers Towards Intercultural Education in Schools
}

Domnița Florina Fetti (Mora) 


\title{
The Attitude of Teachers Towards Intercultural Education in Schools
}

\author{
Domnița Florina Fetti (Mora) ${ }^{a^{*}}$ \\ ${ }^{a}$ Doctoral School "Education, Reflection, Development", Faculty of Psychology and Educational Sciences, Babeș-Bolyai University, Cluj-Napoca, 7 \\ Sindicatelor Street, 400029, Romania \\ *Corresponding author:florina_mora@yahoo.com
}

\section{Abstract}

\section{Keywords:}

culture; interculturality; intercultural education; Intercultural conflicts.
Promoting an intercultural perspective in education must rely on a certain vision upon society. Given the special significance in educational approaches, the intercultural approach is a new way of designing and implementing the school curriculum and a new relational attitude among teachers, students and parents. The intercultural perspective opens new avenues for the manifestation of diversity and differences. Intercultural positioning is not reduced to a cumulative presentation of knowledge about the values of others, but it means cultivating attitudes of respect and openness to diversity. This attitude is born through a permanent communication with others and through a careful and optimal decentralization towards one's own cultural norms. Therefore, the management of the intercultural conflicts made in the context of school learning experiences must be related to the dynamic perspective on the changes that characterize the educational reality in terms of educational innovation. As a consequence, a pertinent analysis of this phenomenon is required, in order to bring the necessary restructuring in order to optimize school activity and prevent conflict management between students belonging to different cultures, being known the fact that the more elaborate the interaction, the more effective and productive it becomes.

\section{Zusammenfasung}

\section{Schlüsselworte:}

Kultur; Interkulturalität; interkulturelle Bildung; interkulturelle Konflikte.
Die Förderung einer interkulturellen Perspektive in der Bildung muss auf einer bestimmten gesellschaftlichen Vision basieren. Angesichts der besonderen Bedeutung in Bildungsansätzen ist der interkulturelle Ansatz eine neue Art der Gestaltung und Umsetzung von Schullehrplänen und eine neue Beziehungshaltung zwischen Lehrern, Schülern, Eltern. Die interkulturelle Perspektive eröffnet neue Wege für die Manifestation von Vielfalt und Unterschieden. Interkulturelle Positionierung reduziert sich nicht auf eine kumulative Präsentation von Wissen über die Werte anderer, sondern bedeutet, eine Haltung des Respekts und der Offenheit für Vielfalt zu pflegen. Diese Haltung entsteht durch eine permanente Kommunikation mit anderen und durch eine sorgfältige und optimale Dezentralisierung auf die eigenen kulturellen Normen. Daher muss die Herangehensweise an das Thema interkultureller Konflikte im Kontext schulischer Lernerfahrungen mit der dynamischen Perspektive auf die Veränderungen verknüpft werden, die die Bildungsrealität im Hinblick auf Bildungsinnovation charakterisieren. Daher ist eine entsprechende Analyse dieses Phänomens erforderlich, um die notwendigen Umstrukturierungen herbeizuführen, um den Schulbetrieb zu optimieren und Konflikte zwischen Schülern unterschiedlicher Kulturen zu verhindern, zu verbessern, ist bekannt, dass die Interaktion umso effektiver wird, je aufwendiger sie ist. und produktiv.

\section{Introduction}

The school is a microcosm in which a specific culture is promoted, which is as dynamic and unpredictable as the "external" culture. Thus, the school, as a social institution, must reunite and recompose the intrinsic plurality of culture, to meet diversity.

In the broadest sense, "culture today can be considered as the set of distinctive, spiritual and material, intellectual and affective traits that characterize a society or a social group. It encompasses, in addition to the arts and letters, ways of life, fundamental human rights, value systems, traditions and beliefs. Culture gives man the ability to reflect on himself. Man expresses himself through it. He tirelessly seeks new meanings and creates works that transcend him" (Dasen, Perregaux \& Rey, 1999, p. 85).

We figure out from Perregaux's definition that this culture should no longer be understood as a finite sum of particular traits that comes with stereotypes, and the intercultural approach thus becomes possible in so far as it is admitted that the negotiations which establish connections among individuals belonging to different cultures may lead to the creation of new cultural practices, value transfers, new conjunctions between their different sequences. With the emergence of some 
contacts among several cultures, new cultural practices are created, carrying new meanings.

\section{Theoretical foundation}

Intercultural education has appeared on Europe's political agenda with the schooling of immigrants' children in Western European societies. It was then acknowledged for the first time that the existence of groups that have a cultural background different from that of the majority population can be a challenge.

Related to conceptualization, we find that the term intercultural communication was first used by Edward Hall (1959) in the paper named "Silent Language", where he addresses issues related to the importance of nonverbal behaviour in communication, defining nonverbal communication as an exchange that does not involve words.

In his turn, Constantin Cucoş defines intercultural communication as an "exchange or value transaction accompanied by the understanding of the adjacent meanings, among persons or groups who/which are part of different cultures. Exchanges can be made at the ideational, verbal, nonverbal, behavioural, physical, objective, organizational level" (Cucoș, 2000, p.136).

Cultural diversity is no longer a prejudice, but a reality that must be fruitful in the school environment. Cultural plurality raises not only the problem of defending differences, but of cultural dialogue, which recognizes that each must contribute to the enrichment of human experience and that each culture is an effort to universalize a particular experience.

The idea of intercultural dialogue must have as a starting point the recognition of the difference and the multiple perspectives and dimensions of the world we live in. That is why, "the dialogue, communication or intercultural mediation aim to analyze these diverse perspectives with a precise purpose, namely to understand and learn based on diverse intercultural experiences" (Cozma, 2001, p. 179).

The ability to interact and communicate effectively also involves the ability to resolve communication conflicts that may arise. Conflict does not necessarily involve only negative aspects (e.g. tension, quarrel or physical confrontations). There can also be positive effects of conflicts:

1. increasing interest and motivation for change;

2. improving the process of identifying problems and solutions;

3. increasing the cohesion of a group in the event of joint conflict resolution;

4. developing the capacities of individuals to adapt to reality;

5. offering opportunities for knowledge and development of practical skills for solving states of uncertainty;

6. developing creativity and ingenuity to find optimal solutions, etc.

In any field, "the existence of conflicts must be accepted as part of the process of interpersonal interaction while communication must respect the rules for resolving these conflict states" (Cucoș, 2000, p. 178). That is why conflicts are usually regarded as part of the process of interaction and communication.

Depending on the opportunity or inopportuneness of the conflict within the school organization, there are three fundamental concepts (Coste, 1995, p. 142):

a) traditional - considers the conflict harmful for schools, and its appearance represents a failure of the principles of educational management;

b) behavioural - considers conflict a common phenomenon in the life of organizations, because their members have various needs, interests, abilities, etc. which often collide with each other. That conception regards conflict as something normal where people work together;

c) interactionist, currently dominant, considers the conflict inevitable and even necessary, because it requires the search for solutions, stimulates thinking and creativity.

The core of the concept of "intercultural education" is: the dialogue of cultures, the understanding among cultures, the value and originality of each culture, comprehension among communities. A comprehensive definition is found in the author Micheline Rey, where the term "intercultural" is used both because of the rich meaning of the prefix "inter" and the (anthropological) meaning of the word "culture". Thus, when we say intercultural, we necessarily mean interaction, exchange, reciprocity, interdependence, solidarity. We also say: the recognition of the values, of the ways of life, of the symbolic representations to which the human beings, the individual or the groups refer in the relations with the fellows and in the understanding of 
the world; recognizing the interactions that occur at a given time between multiple aspects of the same culture and between different cultures in time and space (Dasen, Perregaux \& Rey, 1999, p. 152).

Intercultural education is today in the attention of all the education systems and all the educators. And they are a result of social learning whose mission is constantly expanding. The task of this pedagogy is, according to the same Micheline Rey, to ensure the transition from an egocentric thinking to a solidary thinking, which would favour cooperation more than competition. Among the competencies, knowledge and privileged concerns of the professor, the author lists (Rey, 1999, pp. 186-187):

a) the democratic organization of classes (groups);

b) experiencing different social roles (including animators, leaders);

c) to follow the quality of the relations among the students in the service of promoting the prestige of each one;

d) to control the phenomena of violence;

e) to ensure the observance of the rights of all categories of minorities;

f) to ensure the opening of the group to the outside.

The learning activity becomes learning of acceptance of otherness, a process of formation of cultural maturity materialized in the intercultural competence. As a goal of education for diversity, intercultural competence "means that relational ability to relate to people from other cultures, demonstrating permissiveness, respect and understanding of diverse cultural meanings" (Cucoș, 2000, p. 213). But to form this competence in the educated individual according to the informative side, does not mean just the presentation of knowledge or an ideology, but involves a deliberate action of training and transforming the personality of the educated by constantly relating to the principles of flexibility and cultural openness. In this educational situation, teachers are faced with problems that involve the preexistence of intercultural competence even in the educators themselves. Intercultural education emphasizes the need to reorient to a pedagogy of models and emphasizes the role of training teaching skills in achieving effective educational acts.
In conclusion, today's society requires the teacher to be trained from an intercultural perspective in order to facilitate the spiritual and cultural permeability of students. Accepting otherness and interdependence, creating the conditions for expressing the other's personality, laying the foundations of a solidary behaviour, must represent the objectives of any teacher involved in the educational process. If the teacher can make the new generations recognize the essential role of interdependencies and interactions, learn a more dynamic way of human rights, then it can be hoped that students will be prepared to meet the new demands of today's society: intercultural openness.

\section{Research methodology}

The research undertaken has as a starting point the measurement of the teachers' attitude towards intercultural education, on the three operationalized dimensions of the concept of "attitude", namely: knowledge, perceptions and behaviours related to intercultural education.

The purpose of this research was to determine the extent and manner in which teachers promote and use intercultural education in various school subjects.

The fundamental objective of this research was to study the way in which teachers put into practice the principles of intercultural education in schools with an interethnic composition of students. Within the general objective, there are several specific objectives that we will pursue during the research:

1. Identifying the level of knowledge of the respondents regarding the intercultural education, and interculturality in the broad sense of the term;

2. Determining the behaviours of teachers, related to the coexistence of several ethnic groups in the school environment in which they work or attend.

The method used in this approach is mainly the investigation. We have chosen this method because it involves a direct exchange of information between the researcher (me in this case) and the subjects under investigation (teachers), in which we will collect data on their attitude towards intercultural education. The arguments for which we opted for this method can be found in an attempt to describe as objectively as possible the way in which teachers promote intercultural education in different subjects, but also the attitude they have towards achieving intercultural education in order to prevent and alleviate conflicts 
between majority and minority students. The specific tool used in this survey is the questionnaire. The survey technique used is the indirect one, in which the teachers answer the questions formulated in writing. The questionnaire was applied to 100 teachers from different high schools in Cluj-Napoca and Bistrita. Teachers were randomly chosen.

The concept of attitude has been operationalized in a three-dimensional research, which will be presented in turn in this section. The first dimension concerns the respondents' knowledge about intercultural education, and interculturality in the broad sense of the term. Then, the conclusions on the dimension of perceptions regarding intercultural education will be presented, and finally the dimension of the behaviours of teachers, students and parents will be addressed, related to the coexistence of several ethnic groups in the school environment in which they work or attend.

\section{Results}

The teachers' answers to the first question helped us form an image of the knowledge they had about intercultural education. Thus, the teachers mastered very well the key terms related to the intercultural phenomenon. It is primarily about the cultural diversity between the majority and the minority groups, the multicultural space where these groups coexist. In fact, they also figured out the purpose of the intercultural education: to reduce discrimination between minority and majority groups.

Figure 1. Frequency of words related to intercultural education

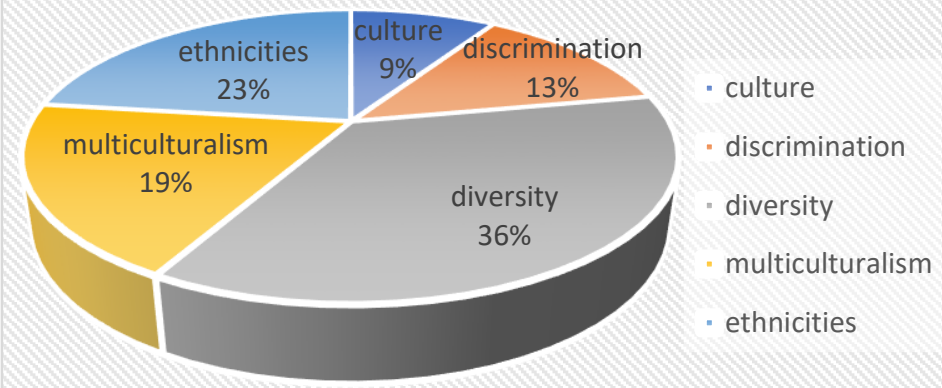

In figure 2 we notice that a great importance is given in schools to intercultural education and only some teachers do not know much about it. 39\% of teachers consider it very important to include and promote intercultural education in schools. With a higher percentage, in case of $42 \%$ of teachers the importance of implementing an optional class on "intercultural education" in ranked second, considering it not essential but only important. Teachers who deny the importance of intercultural education in school are 12\%. Many of them do not place much value on the promotion of intercultural education due to the fact that they do not have much information about it and due to the lack of the inservice training on this topic. There are teachers who do not know (7\%) whether intercultural education is beneficial or not in the instructive-educational process in school.

Figure 2 The importance of the intercultural education in schools

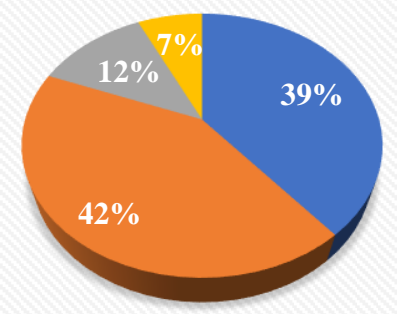

$$
\begin{aligned}
& \text { Very important } \quad \text { Inportance } \\
& \text { It doesn't matter } \square \text { I do not know }
\end{aligned}
$$

Teachers consider that it is very important to know the culture of others ( $43 \%$ ), in order to be able to teach intercultural education in school. It is also important for the teacher to relate effectively with students, to communicate and adapt the educational content to the age and psychological level of the child. Thus, $29 \%$ of teachers consider that having the ability to maintain educational relationships with others and have knowledge in the field is essential.

Unfortunately, teachers do not place much emphasis on the methodology for conducting intercultural education, only $7 \%$ of them considered it important to know this aspect. Without the application of a correct methodology, teachers may erroneously apply the principles of intercultural education, so it is necessary to take specialization courses on this topic.

Figure 3 Skills required for teaching the intercultural education

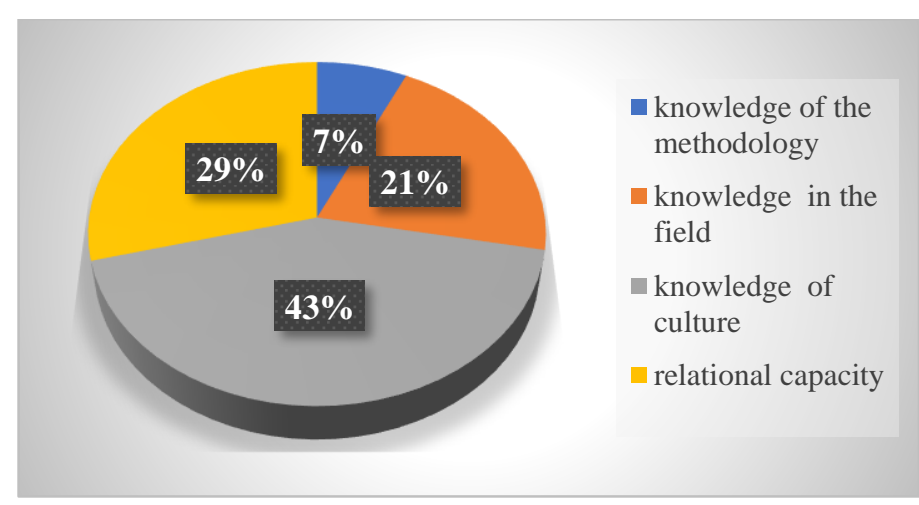


Regarding the knowledge and skills that students can acquire through intercultural education, teachers believe that students must first know the culture of the other colleague (27 teachers consider it important to know the culture of the other) which is not the same ethnicity. It is very important to approach other cultures in different subjects, to highlight their riches and traditions in order to familiarize children and to achieve cultural openness.

Figure 4 . Knowledge and skills acquired by students

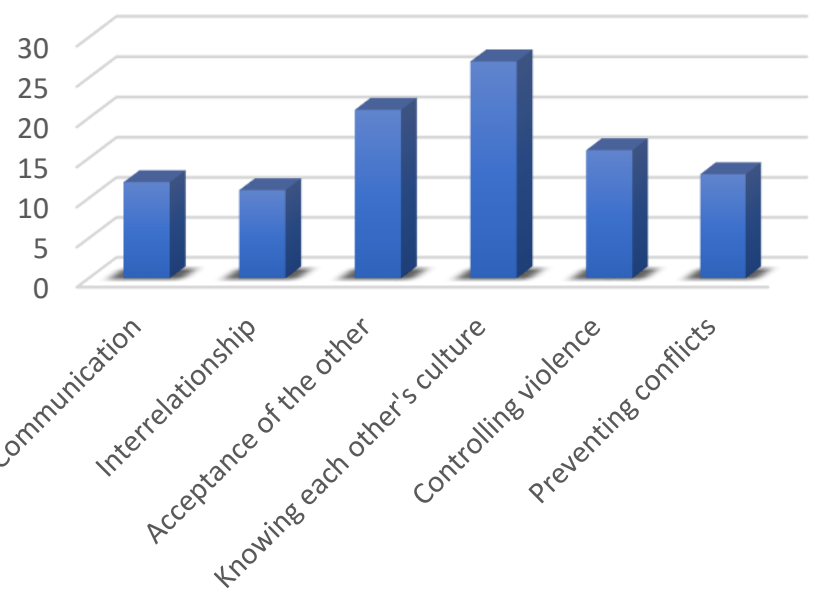

Teachers (21 of the total number) consider it important to accept those around us, even if we are not part of the same culture, do not share the same faith and do not speak the same language. Teachers believe that there is an urgent need for intercultural education in order to prevent and eliminate conflicts between majority and minority students. Unfortunately, there are many conflicts between these students and that is why we must intervene with methods that involve cooperation, acceptance and relationships with others. Children need to be trained in certain disciplines to accept each other because we are all equal, to resolve conflicts amicably and to communicate, to socialize without putting labels and without judging those around us.

In figure 5 we notice that most teachers apply the principles of intercultural education occasionally or very little, only when some proposed topics require an intercultural approach.
Figure 5 The employment of the intercultural education

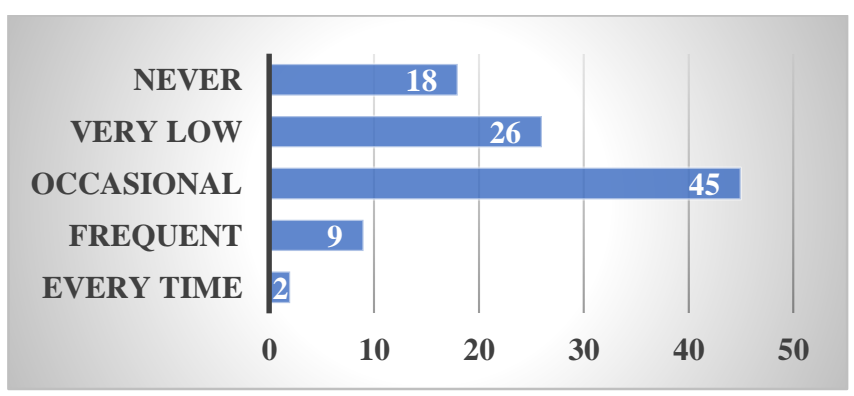

Unfortunately, when it comes to applying intercultural education to the classroom, things are not going very well. Only $2 \%$ of teachers work interculturally in any circumstance of teaching activity. Most teachers (45\%) occasionally apply intercultural education in the classroom.

\section{Discussions}

From this analysis obviously emerged the training needs of teachers, but also the obstacles that hinder the emergence of a genuine interculturality in the educational system in Romania.

The picture that this research has outlined is far from optimistic. The obstacles that hinder the emergence of interculturality in the educational system in Romania are numerous, deeply rooted and difficult to eradicate. The main failure factor of the penetration of intercultural education in schools is the strong deficit of initial teacher training in the field, coupled with unstructured in-service education, sometimes of poor quality, sometimes supported by amateur pedagogical supports and trainers who sometimes transmit their own stereotypes, instead of awakening a real reflection on prejudices and discriminatory attitudes.

Despite the development of literature and the maturation of the debate in the field of intercultural education and globalization, we have very few signals of transfer or didactic transposition of these topics in the practice of the Romanian school.

Therefore, no matter how willingly the intercultural curriculum is accepted in the national curriculum, through the School Customized Curriculum, as an optional subject or included in the national curriculum containing the compulsory subjects, it remains underexploited in the school for the time being. But how can we define the intercultural curriculum?

The attempts to define intercultural curriculum should not be considered through eliminating the 
definitions given to the curriculum in general; also, the intercultural curriculum should not be perceived as a separate, distinct component of the curriculum or education, but an integrated element of them, a segment included in the general curriculum. In other words, we can define the intercultural curriculum as the set of educational processes and learning experiences that allow students to learn the principles of cultural pluralism, tolerance, but also human rights, acceptance of diversity, acquisition of intercultural skills. The intercultural curriculum is positioned in the same stages of elaboration (Cretu, 2001), of any curriculum the emphasis falling on objectives and not on contents, although in terms of intercultural training they are of great importance, aiming at either a relatively new issue or different ways of relating to them.

\section{Conclusions}

Therefore, the knowledge regarding intercultural education is deepened only where the interculturality guides transversally the way in which the educational process takes place, being not only well understood by the teachers, but also applied in the daily pedagogical practice. Otherwise, the understanding of interculturality is superficial, theoretical, and in certain situations this superficial understanding jeopardizes the very achievement of the purpose of intercultural education, namely the eradication of stereotypes about otherness and respect for diversity in equity.

If there is still a lot of work to be done in the field of intercultural knowledge, the ground seems conducive to sowing the seeds of interculturality: teachers' perceptions of intercultural education are generally positive. The subject is seen as something useful and desirable, but at the same time pleasant, both for teachers, for students and parents. Sometimes, the attractiveness of intercultural education seems to reside in the novelty of the theme for education in Romania; even if this perception risks disappearing with the deeper acquaintance with the concepts of intercultural education, thus being a surface attraction for the issue, it must be exploited to take advantage of the openness that seems to benefit among teachers.

At the level of multicultural behaviour, however, the situation is worrying. If certain knowledge about interculturality is found in the discourse of some of the interviewed teachers, they remain at a theoretical and formal level, not being transposed in the daily pedagogical practice.

In conclusion, today's society requires that the teacher is trained from an intercultural perspective to facilitate the spiritual and cultural permeability of students. To accept otherness and interdependence, to create the conditions for expressing the other's personality, to lay the foundations of a solidary behaviour, must represent the objectives of any teacher involved in the educational process. If the teacher can make the new generations of learners to acknowledge the essential role of interdependencies and interactions, to learn a more dynamic way of human rights, then one can hope that students will be prepared to meet the new demands of today's society: intercultural openness.

\section{Authors note:}

Domnița Florina Fetti (Mora) is currently a $\mathrm{PhD}$ student at the Doctoral School "Education, Reflection, Development", Babeș-Bolyai University, ClujNapoca, Romania, and teacher at George Barițiu National College in Cluj-Napoca. Her interests are related to the development of emotional resilience of primary school students and the acquisition of emotional and social skills.

\section{References}

Coste, V. (1995). Managementul în școli. Iași: Editura Spiru Haret.

Cozma, T. (2001. O nouă provocare pentru educație: interculturalitatea. Iași: Editura Polirom.

Creţu, C. (2001). Curriculum intercultural, catalizator al globalizări. In Teodor Cozma (coord.). $O$ nouă provocare pentru educaţie: interculturalitatea. Iași: Editura Polirom.

Cucoș, C. (2000). Educația - dimensiuni culturale și interculturale. Iași: Editura Polirom.

Dasen, P., Perregaux, C., \& Rey, M. (1999). Educația interculturală. Experiențe, Politici, Strategii. Iași: Editura Polirom.

Hall, E. (1990). The silent language, New York: Anchor Books/ Doubleday.

Rey, M. (1999). De la o logică „mono” la logica de tip „inter”. Piste pentru o educaţie interculturală şi solidară. In Dasen, P., Perrgaux, C., \& Rey, M. (eds). Educaţia interculturală. Iași: Editura Polirom. 